\title{
Microsatellite cross-species amplification in the genus Centaurea (Compositae)
}

\section{S. LÓPEZ-VINYALLONGA ${ }^{1}$, J. LÓPEZ-ALVARADO ${ }^{1,2}$, TH. CONSTANTINIDIS $^{3}$, A. SUSANNA ${ }^{1} \&$ N. GARCIA-JACAS ${ }^{1}$}

\author{
${ }^{1}$ Botanic Institute of Barcelona (IBB-CSIC-ICUB), Psg. del Migdia s/n., E-08038 Barcelona, Spain \\ ${ }^{2}$ Dipartimento di Botanica ed Ecologia Vegetale, Facoltà di Scienze Matematiche, Fisiche e Naturali, \\ Università degli Studi di Sassari, Via Muroni 25, I-07100 Sassari, Italy \\ ${ }^{3}$ Department of Ecology \& Systematics, Faculty of Biology, National \& Kapodistrian University of Athens, \\ Panepistimiopolis, 15784 Athens, Greece
}

Author for correspondence: S. López-Vinyallonga (slopez@ibb.csic.es)

Editor: R. Vilatersana

Received 22 August 2011; Accepted 3 October 2011

\begin{abstract}
Microsatellite cross-species amplification in the genus Centaurea (Compositae).- Microsatellites are widely used for population genetic studies although the development of these species-specific markers is costly and time-consuming. One strategy for saving time and money is the use of markers developed for one species (source species) in a different species (target species). This is known as cross-amplification. In the present work, two sets of microsatellites are used to test their transferability to six narrow endemic Centaurea species: i) 16 nuclear loci previously published for three congeneric species and ii) 10 universal chloroplast markers designed from Nicotiana tabacum sequences. Seventeen of the 26 markers tested were transferable and 14 of them were also polymorphic and therefore useful for future works. Nuclear markers were more variable and thus more informative than chloroplast markers. Interspecific amplification performed better for the nuclear loci developed for different Centaurea species than for the universal chloroplast markers developed for Nicotiana tabacum. Likewise, transferability was more successful for the species from sect. Phalolepis than for sect. Lepteranthus. Therefore, our results support the idea that the success of the cross-amplification is influenced by the evolutionary distance between the target and the source species.
\end{abstract}

Key words: chloroplast microsatellites; conservation; cross-amplification; interspecific amplification; narrow endemics; SSR; transferability; universal markers.

\footnotetext{
Resumen

Amplificación cruzada de microsatélites en el género Centaurea (Compositae).- Los microsatélites se usan habitualmente en estudios de genética de poblaciones aunque su desarrollo es un proceso caro y largo dada su elevada especificidad. Una estrategia que permite ahorrar tiempo y dinero es la llamada amplificación cruzada que consiste en amplificar el DNA de una especie determinada (especie objetivo) usando marcadores que han sido diseñados para una especie diferente (especie fuente). En este trabajo se ha realizado un ensayo sobre amplificación cruzada usando seis endemismos del género Centaurea y dos conjuntos de microsatélites: i) 16 marcadores nucleares desarrollados para tres especies congenéricas y ii) 10 marcadores cloroplásticos universales diseñados para Nicotiana tabacum. Diecisiete de los 26 marcadores evaluados resultaron transferibles, de los cuales 14 fueron polimórficos siendo así útiles para futuros trabajos. Las regiones nucleares se mostraron más variables y por lo tanto más informativas que las cloroplásticas. La amplificación cruzada funcionó mejor para los marcadores nucleares específicos de Centaurea que para los cloroplásticos universales específicos de Nicotiana tabacum. A su vez, se obtuvo mejor resultado para las especies de la sección Phalolepis que para las de la sección Lepteranthus. En consecuencia, nuestros resultados apoyan la idea de que el éxito de la amplificación cruzada está estrechamente ligado a la distancia evolutiva entre especie fuente y especie objetivo.
}

Palabras clave: amplificación cruzada; amplificación interespecífica; conservación; marcadores universales; microendemismos; microsatélites cloroplásticos; SSR. 


\section{INTRODUCTION}

Single Sequence Repeats (SSR), also known as microsatellites, are widely used to investigate genetic variability and structure both at population and species level. These genetic markers are tandemly repeated units from one to six nucleotide in length distributed evenly throughout the genome and present in almost every organism so far studied (Hancock, 1999). Their main advantages are i) high polymorphism derived from a high mutation rate, ii) codominant inheritance and iii) multiallelic nature.

The process of SSR isolation is expensive and time consuming since they usually have to be designed and optimized ex novo for each species separately. To avoid these drawbacks, the use of primer sequences developed for one species (source species) into others (target species) is desirable in terms of cost-efficiency. Ideally, the development of universal primers would minimize both time and costs necessary to carry out microsatellite works. The main weakness of this strategy is the low variability recovered in most cases because universal primers often amplify loci in coding regions. Different studies have used this approach mainly for chloroplast DNA (e. g. Weising \& Gardner, 1999; Chung \& Staub, 2003) and Expressed Sequence Tags (EST, e. g. Peakall et al., 1998; Heesacker et al., 2008). Regarding chloroplast microsatellites, Ebert \& Peakall (2009) state that "when genus-specific cpSSR primers are available, cross-species amplification can often be fruitful". Nevertheless, they point out that "while potentially useful, universal cpSSR primers at best provide access to only a small number of variable markers". In addition, an important limitation of cpDNA markers is that they constitute a single linkage group. EST-derived markers come from transcribed regions of the genome, so they are likely to be conserved across a broader taxonomic range than markers derived from total genomic DNA. Pashley et $a l$. (2006) found that this kind of marker was more than 3 times as transferable across species than were the anonymous SSRs derived from genomic DNA ( $73 \%$ vs. $21 \%$, respectively). However, according to Kantety et al. (2002) the frequency of SSR-containing sequences in plant-derived EST databases is only around $2 \%$ and $5 \%$.

Therefore, as a starting point for a population genetic study in a given species, it is worth testing markers previously developed for congeneric plants if these are available, in few individuals. If they are useful, there is no need to look for new loci, saving time and money. If amplification fails or these loci are monomorphic, development of specific microsatellites will be necessary.

According to Barbará et al. (2007) the success of the cross-amplification is highest in species with long generation times, mixed or outcrossing breeding systems, and when genome size in the target species is small compared to the source. In addition, negative association between evolutionary distance and cross-species amplification success has been reported by several authors (e. g. Primmer et al., 1996; Eujayl et al., 2004; Saha et al., 2004; Guo et al., 2006). This phenomenon is explained primarily because polymorphisms in sequences flanking repeats increase as phylogenetic distances increase. As an example, Heesacker et al. (2008) found that of the 466 markers developed for Helianthus annuus L. successful cross-amplification was achieved for $88.6 \%$ of the loci in sunflower wild relatives $H$. anomalus S. F. Blake, $H$. argophyllus Torr. \& A. Gray, $H$. deserticola Heiser, $H$. paradoxus Heiser and $H$. tuberosus L. whereas only around $14 \%$ of the loci amplified alleles from distantly related species such as Carthamus tinctorius L. and Lactuca sativa L.

Taking into account all these considerations, in the present work we will test the transferability of 26 microsatellite markers previously developed for Nicotiana tabacum L., Centaurea corymbosa Pourr., C. diffusa Lam. and C. stoebe L. to six narrow endemic Centaurea L. species from two different sections, Lepteranthus (Necker) DC. and Phalolepis (Cass.) DC. (sensu Dostál, 1976).

Our goals are:

To investigate if the cross-amplification performs better with phylogenetically closer species using microsatellite nuclear markers.

To verify usefulness of SSR markers within the Greek group of narrow endemics from sect. Phalolepis.

\section{MATERIALS AND METHODS}

\section{Plant material}

Studied material comprises six narrow endemic Centaurea species.

Centaurea emigrantis Bubani is a perennial herb from sect. Lepteranthus restricted to the Pre- 
Pyrenean Mountains of Serra del Montsec (Spain). It grows in shrubby and open habitats up to $1400 \mathrm{~m}$. Despite its narrow range of distribution it can be locally abundant and has been considered as LC (Least Concern) following the IUCN criteria (Aymerich \& Sáez., 2010). It is a diploid plant with $2 n=22$ (Arnelas Seco \& Devesa, 2010).

The group of narrow endemics from sect. Phalolepis in Greece is composed of Centaurea chrysocephala Phitos \& T. Georgiadis, C. heldreichii Halácsy, C. litochorea T. Georgiadis \& Phitos, $C$. messenicolasiana T. Georgiadis, G. Dimitrellos \& Routsi and C. princeps Boiss. \& Heldr.

Centaurea chrysocephala is a biennial or perennial plant known from a few localities in Central Greece, where it forms small populations. It prefers rocky places and cliffs but can also be found in stony places, road margins and walls, on limestone, sandstone, serpentine and conglomerate substrates. It is a diploid with $2 n=18$ (Routsi \& Georgiadis, 1988) and has been characterized as R (Rare) by Anagnostopoulos \& Constantinidis (1995).

Centaurea heldreichii is a perennial plant endemic to western Greece. It is known from a single population on the rocks and cliffs of Mt. Paliovouna (Western Sterea Ellas), at an altitude of 3-600 m. The species is considered VU (Vulnerable), cf. Phitos et al. (2009) and its total population is estimated at around 4000-8000 individuals, both mature and juvenile. It is a diploid with $2 n=18$ (Phitos \& Damboldt, 1971).

Centaurea litochorea is a biennial or perennial plant known from a few localities of the Olympos and Kato Olympos mountains, North-Central Greece. It grows at an altitude of $830-1800 \mathrm{~m}$ on stony calcareous substrates. Its known populations may contain less than 5000 individuals in total. The species has been characterized as VU (Vulnerable) by Constantinidis (2009) and is possibly extinct at its locus classicus. As far as we know, the only chromosome number reported for this diploid species is $2 n=16$ (Strid \& Franzen, 1981). Since the basic chromosome number for sect. Phalolepis is $x=9$ (Hilpold, in prep.), we decided to repeat the count with our material and we obtained $2 n=18$, which is in agreement with the basic number for the section. Therefore we consider that the report by Strid \& Franzen (1981) is inaccurate and should be discarded.

Centaurea messenicolasiana was described in 1996 and is a very local species, found in a small area at the foothills of Mount Agrapha, to the north- east of Tavropos artificial lake (Central Greece), at 500-800 m. It forms small groups of 10-60 individuals in an area of $c .4 \mathrm{~km}^{2}$, mostly in openings and margins of deciduous forests, on flysch. The species has been characterized as VU (Vulnerable) in Georgiadis et al. (2009). It is a diploid with $2 n=18$ (Georgiadis et al., 1996).

Centaurea princeps is a local endemic only known from Mount Timfristos of Central Greece. It is a biennial growing in limestone cliffs and scree, at an altitude of $1100-1850 \mathrm{~m}$. It is taxonomically related to C. chrysocephala and C. messenicolasiana and diploid, with $2 n=18$ (Garcia-Jacas, unpublished data). It is a threatened plant, characterized as VU (Vulnerable) by Georgiadis \& Dimitrellos (2009).

Localities of the material used and voucher specimens information are listed in Table 1 . In addition, a picture of each species is provided in Fig. 1.

\section{DNA isolation and microsatellite loci}

Genomic DNA was extracted from dried leaf tissue using the CTAB method by Doyle \& Doyle (1987) as modified by Cullings (1992) and Tel-Zur et al. (1999). In order to increase the detection of polymorphism in this preliminary screening, individuals within a species were selected from different populations when possible. Ten individuals each from a total of 15 wild populations representing the six species were sampled (Table 1).

In this cross-amplification assay, two sets of microsatellites were used: i) nuclear markers: seven SSR loci previously developed for $C$. corymbosa (Fréville et al., 2000) and nine SSR loci previously developed for C. diffusa and C. stoebe (Marrs et al., 2006), all three species from sect. Centaurea [=Acrolophus (Cass.) DC.] and ii) $10 \mathrm{cpDNA}$ markers designed for Nicotiana tabacum (Weising \& Gardner, 1999). See Table 2 for details. All SSR loci were amplified using FAM, NED, PET and VIC fluorescently labeled forward primers as explained in López-Vinyallonga et al. (2010). Different profiles were used for the amplification following the conditions established for each locus in the original publications (Table 2). The six target species were amplified with the nuclear markers while five species were amplified with the chloroplast set (C. emigrantis was not included in this assay). Genotyping was performed on an ABI 3730xl DNA Analyzer (Applied Biosystems, Fos- 
Table 1. Voucher information and sources of material of the six species included in this work.

\begin{tabular}{|c|c|}
\hline Species & Voucher \\
\hline \multirow{5}{*}{ C. chrysocephala Phitos \& T. Georgiadis } & $\begin{array}{l}\text { Greece, Nomos Trikalon, Eparchia Kalampakas, Mt. Kerketion Oros, } \\
\text { c. } 1 \mathrm{~km} \text { E of the village of Klinovo, } 39^{\circ} 39^{\prime} 59.32^{\prime} \mathrm{N}, 21^{\circ} 28^{\prime} 19.26^{\prime} \text { E, } \\
\text { Garcia-Jacas, Karamplianis \& Susanna } 2742 \text { (BC). }\end{array}$ \\
\hline & $\begin{array}{l}\text { Greece, Nomos Trikalon, Eparchia Kalampakas, Mt. Kerketion Oros, } \\
\text { c. } 1 \mathrm{~km} \text { N, main road Kastania- Kalampaka, 39 43’2.73” N, } \\
20^{\circ} 59^{\prime} 39.12^{\prime \prime E} \text {, Garcia-Jacas, Karamplianis \& Susanna } 2749 \text { (BC). }\end{array}$ \\
\hline & $\begin{array}{l}\text { Greece, Nomos Trikalon, Ep. Kalampakas, W-facing vertical rocks } \\
\text { and the entrance to the monastery of Varlaam (Meteora), } \\
39^{\circ} 43^{\prime} 25.94 \text { " N, } 21^{\circ} 38^{\prime} 4.08^{\prime} \text { E, Garcia-Jacas, Karamplianis \& } \\
\text { Susanna } 2736 \text { (BC). }\end{array}$ \\
\hline & $\begin{array}{l}\text { Greece, Nomos Trikalon, Ep. Kalampakas, W-facing slopes, near the } \\
\text { entrance of the monastery of Holy Trinity (Meteora), 39 } 43^{\prime} 5.52^{\prime} \mathrm{N} \text {, } \\
21^{\circ} 38^{\prime} 39.92^{\prime} \text { E, Garcia-Jacas, Karamplianis \& Susanna } 2737 \text { (BC). }\end{array}$ \\
\hline & $\begin{array}{l}\text { Greece, Nomos Trikalon, Eparchia Kalampakas, Mt. Kerketion Oros, } \\
\text { c. } 2 \mathrm{~km} \text { SW from Pertouli Ski center to Neraidochori, } 39^{\circ} 32 \text { ' } 12.85^{\prime} \text { N, } \\
21^{\circ} 27^{\prime} 29.21^{\prime} \text { E, Garcia-Jacas, Karamplianis \& Susanna } 2747 \text { (BC). }\end{array}$ \\
\hline \multirow{4}{*}{ C. emigrantis Bubani } & $\begin{array}{l}\text { Spain, Lleida, Àger, near Corçà, road margins, } 42^{\circ} 2^{\prime} 7.11^{\prime \prime} \mathrm{N}, \\
0^{\circ} 41^{\prime} 66^{\prime \prime} \text { E, López-Alvarado \& Figueroa s. } n .(\mathrm{BC}) .\end{array}$ \\
\hline & $\begin{array}{l}\text { Spain, Lleida, Llimiana, along the LV-9121 road to Llimiana, } \\
42^{\circ} 3 \text { ' } 34.26 \text { " N, 0 } 0^{\circ} \text { 53' } 21.71 \text { " E, López-Alvarado \& Figueroa s. } n \text {. (BC). }\end{array}$ \\
\hline & $\begin{array}{l}\text { Spain, Lleida, Camarasa, LV-9311 road to L'Ametlla de Montsec, } \\
\text { road margins, } 42^{\circ} 0^{\prime} 47.88^{\prime} \text { N, } 0^{\circ} 49^{\prime} 32.50^{\prime} \text { E, López-Alvarado } \\
\& \text { Figueroa s. } n . \text { (BC). }\end{array}$ \\
\hline & $\begin{array}{l}\text { Spain, Lleida, Les Avellanes, Vilanova de la Sal, road to the sanctuary } \\
\text { of Mare de Déu de Montalegre, road margins, } 41^{\circ} 52^{\prime} 16.76^{\prime} \text { N, } \\
0^{\circ} 47^{\prime} 55.16^{\prime} \text { E, López-Alvarado \& Figueroa s. } n \text {. (BC). }\end{array}$ \\
\hline C. heldreichii Halácsy & $\begin{array}{l}\text { Greece, Nomos Etolias-Akarnanias, Eparchia Mesolongiou, E of } \\
\text { Krioneri settlement, in the rocky slopes and cliffs of Varasova mountain } \\
\text { and also the lower parts of the mountain with conglomerate, } \\
38^{\circ} 56^{\prime} 14.40^{\prime} \text { N, } 21^{\circ} 51^{\prime} 43.92^{\prime \prime} \text { E, Constantinidis } 10993 \text { (ATHU). }\end{array}$ \\
\hline \multirow{2}{*}{ C. litochorea T. Georgiadis \& Phitos } & $\begin{array}{l}\text { Greece, Nomos Larissis, Ep. Tirnavou, Mt. Kato Olimbos, at the } \\
\text { summit area of Analipsi, below the telecommunication antennas, NW } \\
\text { of the village of Kallipefki, } 39^{\circ} 57^{\prime} 2.16^{\prime} \text { N, } 21^{\circ} 58^{\prime} 39.88^{\prime \prime} \text { E, } \\
\text { Garcia-Jacas, Karamplianis \& Susanna } 2731 \text { (BC). }\end{array}$ \\
\hline & $\begin{array}{l}\text { Greece, Nomos Larissis, Ep. Tirnavou, Mt. Kato Olimbos, openings } \\
\text { in the mixed Abies and Pinus nigra forest, near the summit area E of } \\
\text { the village of Kallipefki, along the main path from the chapel of } \\
\text { Metamorphosis to the village of Kalli pefki, } 39^{\circ} 57^{\prime} 38.99^{\prime \prime} \mathrm{N} \text {, } \\
22^{\circ} 27^{\prime} 43.06^{\prime} \text { E, Garcia-Jacas, Karamplianis \& Susanna } 2732 \text { (BC). }\end{array}$ \\
\hline $\begin{array}{l}\text { C. messenicolasiana T. Georgiadis, G. Dimitrellos } \\
\text { \& Routsi }\end{array}$ & $\begin{array}{l}\text { Greece, Nomos Karditsis, Eparchia Karditsis, c. } 2 \mathrm{~km} \mathrm{~S} \text { and E of } \\
\text { Messenikolas village, along the road to Karditsa, } 39^{\circ} 21^{\prime} 31.07^{\prime} \mathrm{N}, \\
21^{\circ} 45^{\prime} 9.58^{\prime} \text { E, Garcia-Jacas, Karamplianis \& Susanna } 2739 \text { (BC). }\end{array}$ \\
\hline \multirow{2}{*}{ C. princeps Boiss. \& Heldr. } & $\begin{array}{l}\text { Greece, Nomos Evritanias, Eparchia Evritanias, Mt. Timfristos, at } \\
\text { the NW area of the main summit of Koumbi, openings above the } \\
\text { Abies cephalonica zone, } 38^{\circ} 56^{\prime} 6.48^{\prime} \text { N, } 21^{\circ} 51^{\prime} 49.54 \text { " E, } \\
\text { Garcia-Jacas, Karamplianis \& Susanna } 2756 \text { (BC). }\end{array}$ \\
\hline & $\begin{array}{l}\text { Greece, Nomos Evritanias, Eparchia Evritanias, Mt. Timfristos, SE } \\
\text { parts of the mountain, } c .8 .0-8.5 \mathrm{~km} \text { E of Karpenisi, abandoned quarry } \\
\text { in Abies forest and the rocks above it, } 38^{\circ} 56^{\prime} 6.47^{\prime} \text { N, } 21^{\circ} 48^{\prime} 32.96^{\prime} \text { E, } \\
\text { Constantinidis \& Karamplianis s. } n \text {. (ATHU). }\end{array}$ \\
\hline
\end{tabular}



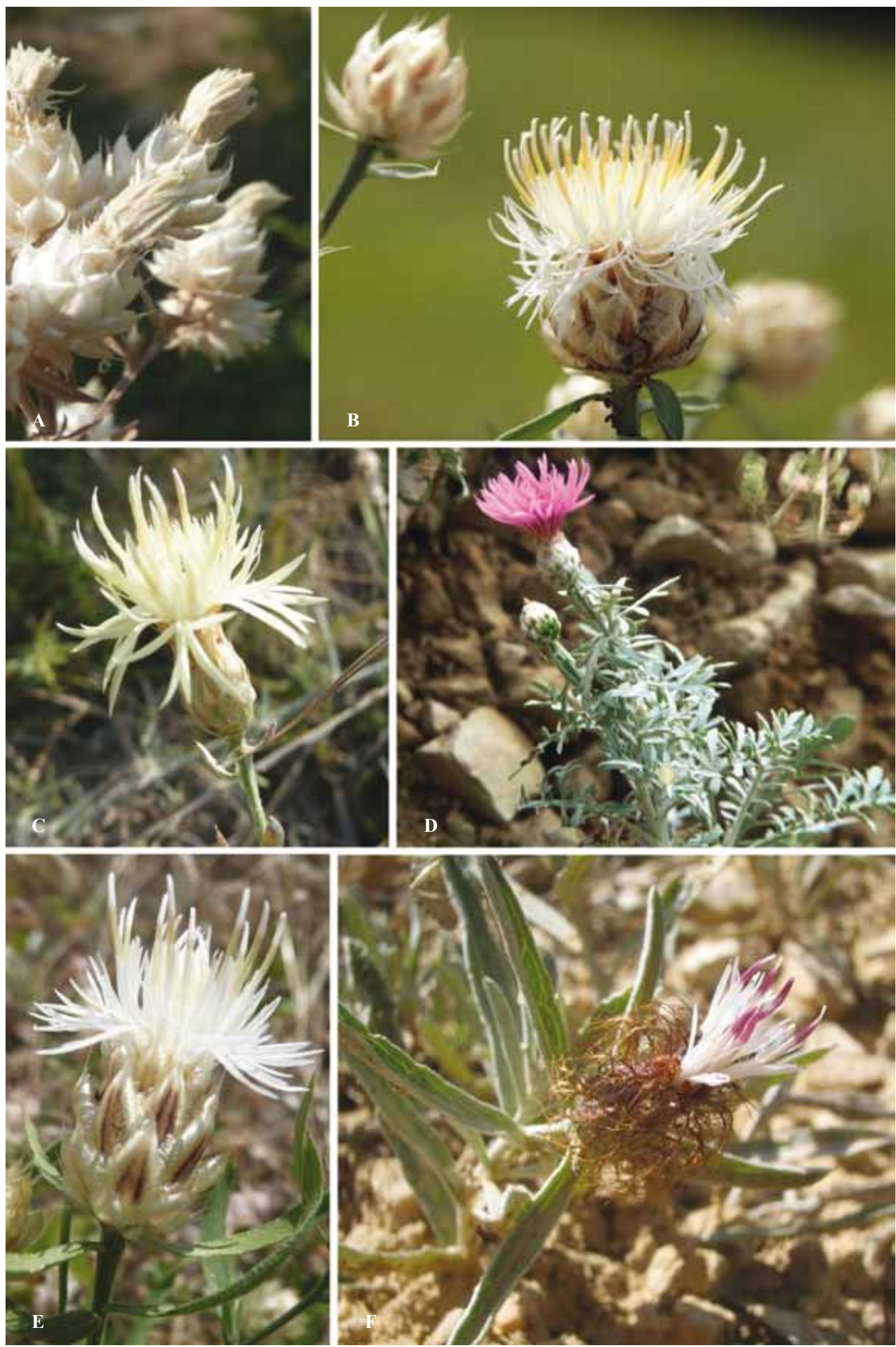

Figure 1. Studied species. (A), Centaurea messenicolasiana; (B), C. princeps; (C), C. litochorea; (D), C. heldreichii; (E), C. chrysocephala; (F), C. emigrantis. 
Table 2. Marker information: locus names, bibliographic references, repeat motifs, size ranges of PCR products and number of alleles observed in the original publications.

\begin{tabular}{|lcccc|}
\hline Loci & Repeat & Size (bp) & No. of alleles & Reference \\
\hline CM26 & $(\mathrm{TG})_{9} \mathrm{~T}(\mathrm{TA})_{3}$ & $133-172$ & 22 & \\
CD37 & $(\mathrm{CA})_{9}$ & $154-176$ & 7 & \\
$21 \mathrm{CM} 36$ & $(\mathrm{CA})_{6}(\mathrm{TA})_{5}(\mathrm{TG})_{16}$ & $187-244$ & 6 & \\
38CM22 & $(\mathrm{GA})_{12} \mathrm{AA}(\mathrm{GA})_{8}$ & $289-344$ & 25 & Marrs et al. (2006) \\
CD9 & $(\mathrm{CA})_{17}$ & $301-325$ & 9 & \\
42CM27 & $(\mathrm{TG})_{14}$ & $155-175$ & 11 & \\
CM15 & $(\mathrm{GT})_{9}$ & $185-220$ & 10 & \\
$25 \mathrm{CM} 6$ & $(\mathrm{CA})_{9}$ & $255-272$ & 7 & \\
CM17 & $(\mathrm{AC})_{9}$ & $379-430$ & 16 & \\
\hline $12 \mathrm{~B} 1$ & $(\mathrm{TA})_{27}(\mathrm{GA})_{22}$ & 168 & 15 & \\
$13 \mathrm{~B} 7$ & $(\mathrm{AC})_{12}(\mathrm{AT})_{5}$ & 163 & 3 & \\
$13 \mathrm{D} 10$ & $(\mathrm{AC})_{7} \mathrm{ATAC}(\mathrm{AT})_{10}$ & 178 & 5 & \\
$16 \mathrm{G} 1$ & $(\mathrm{TA})_{7}(\mathrm{TG})_{8}$ & 144 & 3 & \\
$17 \mathrm{E} 3$ & $(\mathrm{CA})_{11}$ & 102 & 3 & \\
$21 \mathrm{D} 9$ & $(\mathrm{CA})_{20}$ & 135 & 12 & \\
$28 \mathrm{~A} 7$ & $(\mathrm{CA})_{16}$ & 112 & 7 & \\
\hline ccmp1 & $(\mathrm{T})_{10}$ & 139 & - & \\
ccmp2 & $(\mathrm{A})_{11}$ & 189 & - & \\
ccmp3 & $(\mathrm{T})_{11}$ & 112 & - & \\
ccmp4 & $(\mathrm{T})_{13}$ & $-2000)$ \\
ccmp5 & $(\mathrm{C})_{7}(\mathrm{~T})_{10}$ & 126 & - & Weising \& Gardner $(1999)$ \\
ccmp6 & $(\mathrm{T})_{5} \mathrm{C}(\mathrm{A})_{11}(\mathrm{~T})_{5} \mathrm{C}(\mathrm{T})_{17}$ & 103 & - & \\
ccmp7 & $(\mathrm{A})_{13}$ & 133 & - & \\
ccmp8 & $(\mathrm{T})_{6} \mathrm{C}(\mathrm{T})_{14}$ & 77 & - & \\
ccmp9 & $(\mathrm{T})_{11}$ & 98 & - & \\
ccmp10 & $(\mathrm{T})_{14}$ & 103 & - & \\
\hline
\end{tabular}

ter City, CA, USA) at the Interdisciplinary Center for Biotechnology Research (ICBR) facility at the University of Florida. Fragment analysis was performed with GENEMARKER 1.5 (SoftGenetics, LLC, State College, PA) software using 600 LIZ size standard (Applied Biosystems), and data was scored manually. Tables 3 and 4 show the monomorphic or polymorphic nature of each marker for each species considered.

\section{Data analysis}

The software GenAlEx6 (Peakall \& Smouse, 2006) was used to perform the genetic diversity analysis for the six Centaurea species included in this transferability assay. The statistical parameters computed were: the number of alleles; the number of private alleles $(P A)$; the Shannon's Information Index $(I)$ and the observed heterozygosity $\left(H_{\mathrm{O}}\right)$ which represents

Table 3. Nuclear loci tested. Allele number per locus for each species, total number of alleles per each locus and per each species is given. -: failed reaction.

\begin{tabular}{|lcccccccc}
\hline Species & CM26 & CD37 & 21CM36 & 38CM22 & CD9 & 42CM27 & CM15 & 25CM6 \\
\hline C. chrysocephala & - & 3 & - & 5 & - & 6 & - & - \\
C. emigrantis & - & - & 7 & - & - & - & - & - \\
C. heldreichii & - & 1 & - & 1 & - & 4 & - & - \\
C. litochorea & - & 2 & - & 4 & - & 11 & - & - \\
C. messenicolasiana & - & 3 & - & 3 & - & 3 & - & - \\
C. princeps & - & 2 & - & 2 & - & 6 & - & - \\
\hline Total & - & 5 & 7 & 7 & - & 12 & - \\
\hline
\end{tabular}


the percentage of heterozygous individuals in a given sample. All these parameters were calculated both for each species and for each polymorphic locus $\left(H_{\mathrm{O}}\right.$ was not computed for the chloroplast markers because of the haploid nature of this genome). In addition, the percentage of polymorphic loci was computed at the species level. Given the low polymorphism of the chloroplast loci tested (Tables 4 and 5), the genetic diversity statistics at species level where computed using only the nuclear set of markers. Since the chloroplast markers were not amplified for $C$. emigrantis, the diversity values for these loci were computed on the basis of five species instead of six.

\section{RESULTS}

Seventeen (65.4\%) of the 26 SSR markers tested produced consistent cross-amplification in Centaurea and accordingly they were considered as transferable (Tables 3 and 4). Slightly different percentages of marker transferability were recorded for each type of markers; 11 out of 16 nuclear markers tested were transferable $(68.75 \%)$, whereas six out of 10 chloroplast loci assayed were transferable $(60 \%)$. Cross-amplification details for every marker are indicated in Tables 3 and 4.

Within the 17 transferable markers 14 (82.35\%) were polymorphic while $3(17.65 \%)$, all of them from the chloroplast genome, were monomorphic. At the species level, the overall percentage of polymorphic loci for the transferable nuclear markers was $92.5 \%$ ranging from $100 \%$ for $C$. chrysocephala, C. emigrantis, C. litochorea and C. princeps to $75 \%$ for $C$. heldreichii (Table 5). In contrast, the overall percentage of polymorphic loci for the transferable chloroplast markers (excluding the monomorphic ones) was $36.67 \%$ ranging from
$50 \%$ for C. heldreichii and C. messenicolasiana to $16.67 \%$ for $C$. litochorea (Table 5).

All the 11 nuclear loci amplified were polymorphic (Table 3). Within them, three markers (12B1, 13D10 and 28A7) provided good amplification products for the six species tested, five markers (CD37, 38CM22, 42CM27, 17E3 and 21D9) provided good amplification products for five species and three markers (21CM36, CM17 and 13B7) provided good amplification products for just one species. The nuclear locus showing the highest number of alleles was 21D9 (17 alleles amplified from five species) while the lowest number was recovered for locus 13B7 (three alleles, although it is worthy to highlight that it was successfully amplified only for C. emigrantis). The species with the highest number of alleles for the nuclear markers was $C$. litochorea, with 50 alleles from a total of eight markers. In contrast, the species with the lowest number of alleles for the nuclear markers was $C$. heldreichii, with 27 alleles from a total of eight markers. See Table 3 for details.

Among the six chloroplast loci amplified, with the five species tested giving amplification products, three of them were polymorphic with three alleles each (ccmp3, ccmp4 and ccmp5) and the other three were monomorphic (ccmp2, ccmp6 and ccmp7). The species with the highest number of alleles for the six chloroplast markers together were $C$. chrysocephala, C. heldreichii, C. messenicolasiana and $C$. princeps with nine alleles, while the species with the lowest number of alleles was $C$. litochorea, with seven alleles. See Table 4 for details.

Regarding the genetic diversity parameters at species level, the observed heterozygosity ranged from 0.55 (C. chrysocephala) to 0.30 (C. heldreichii) and the Shannon's Information Index ranged from 1.45 (C. chrysocephala and $C$.

\begin{tabular}{ccccccccc|}
\hline CM17 & 12B1 & 13B7 & 13D10 & 16G1 & 17E3 & 21D9 & 28A7 & Total \\
\hline- & 6 & - & 7 & - & 5 & 9 & 6 & 47 \\
7 & 6 & 3 & 2 & - & - & - & 5 & 30 \\
- & 5 & - & 6 & - & 2 & 5 & 3 & 27 \\
- & 6 & - & 3 & - & 6 & 11 & 7 & 50 \\
- & 6 & - & 3 & - & 7 & 1 & 6 & 32 \\
- & 4 & - & 3 & - & 5 & 8 & 4 \\
\hline 7 & 11 & 3 & 11 & - & 10 & 17 & 11 & 34 \\
\hline
\end{tabular}


Table 4. Chloroplast loci tested. Allele number per locus for each species, total number of alleles per each locus and per each species is given. -: failed reaction.

\begin{tabular}{|c|c|c|c|c|c|c|c|c|c|c|c|}
\hline \multirow[b]{2}{*}{ Species } & \multicolumn{11}{|c|}{ Loci } \\
\hline & ccmp1 & ccmp2 & ccmp3 & ccmp4 & ccmp5 & ccmp6 & ccmp7 & ccmp8 & ccmp9 & ccmp10 & Total \\
\hline C. chrysocephala & - & 1 & 2 & 1 & 3 & 1 & 1 & - & - & - & 9 \\
\hline C. heldreichii & - & 1 & 2 & 2 & 2 & 1 & 1 & - & - & - & 9 \\
\hline C. litochorea & - & 1 & 1 & 1 & 2 & 1 & 1 & - & - & - & 7 \\
\hline C. messenicolasiana & $a-$ & 1 & 2 & 2 & 2 & 1 & 1 & - & - & - & 9 \\
\hline C. princeps & - & 1 & 3 & 1 & 2 & 1 & 1 & - & - & - & 9 \\
\hline Total & - & 1 & 3 & 3 & 3 & 1 & 1 & - & - & - & \\
\hline
\end{tabular}

litochorea) to 0.80 (C. heldreichii). Private alleles were found in the six studied species and ranged from 10 in C. litochorea to 1 in C. heldreichii (see Table 6 for details).

As for the genetic diversity statistics across loci (Table 7), the observed heterozygosity ranged from 0.80 (13B7) to 0.20 (38CM22); the Shannon's Information Index ranged from 1.87 (21CM36) to 0.09 (ccmp4) and the number of private alleles ranged from 7 (21D9) to 0 (ccmp5). Since loci 21CM36, CM17 and 13B7 were amplified in one single species, the number of private alleles and the standard deviation values for the remaining parameters could not be computed for these markers.

\section{DISCUSSION}

As stated by many authors (e.g. Primmer et al., 1996; Eujayl et al., 2004; Saha et al., 2004; Guo et al., 2006; Heesacker et al., 2008), cross-amplification is expected to work better for phylogenetically close species, even more when source and target species are congeneric. This can be explained because the similarities in the flanking regions of the microsatellite, where the PCR primers bind to the DNA, are higher in phylogenetically close species than phylogenetically distant species. In our assay, the amplification process was slightly less successful for the set of universal chloroplast markers developed for Nicotiana tabacum, than for the set of nuclear markers developed for different Centaurea species $(60 \%$ and $68.75 \%$ of the loci amplified respectively). Therefore the aforementioned trend is detected in our data but since the source species of the nuclear markers were from genus Centaurea and the chloroplast markers were developed for a phylogenetically very distant species, we expected
Table 5. Percentage of polymorphic loci computed for each species. Chloroplast markers were not tested for C. emigrantis.

\begin{tabular}{|lcc|}
\hline Species & Nuclear loci & Chloroplast loci \\
\hline C. chrysocephala & $100.00 \%$ & $33.33 \%$ \\
C. emigrantis & $100.00 \%$ & - \\
C. heldreichii & $75.00 \%$ & $50.00 \%$ \\
C. litochorea & $100.00 \%$ & $16.67 \%$ \\
C. messenicolasiana & $87.50 \%$ & $50.00 \%$ \\
C. princeps & $100.00 \%$ & $33.33 \%$ \\
\hline Mean & $92.50 \%$ & $36.67 \%$ \\
SD & $5.00 \%$ & $6.24 \%$ \\
\hline
\end{tabular}

higher differences in the transferability success. Yet, although the percentage of amplified loci is similar for both genome types, the percentage of polymorphic loci is strongly higher for the nuclear markers $(92.5 \%)$ compared to the chloroplast markers (36.67\%). The lower variability detected in the cpDNA is in keeping with the slow substitution rate and low rate of structural evolution in the plastid genome relative to the nuclear genome. Moreover, the PCR primers amplifying the chloroplast markers used here were designed in conserved regions of the genome in order to be transferable to many plant species (Weising \& Gardner).

The relationship between evolutionary proximity and success of SSR transfer between source and target species was also tested for Centaurea at sectional level using nuclear markers. The most recent molecular studies in the genus Centaurea (Garcia-Jacas et al., 2006; Suárez-Santiago et al., 2007) have revealed that sections Centaurea, Phalolepis, Willkommia G. Blanca, Jacea (Mill.) DC. and Lepteranthus form a natural group, where the first three sections constitute a monophyletic clade clearly separated from 
Table 6. Number of private alleles $(P A)$, Shannon's Information Index $(I)$ and observed heterozygosity $\left(H_{O}\right)$ for each species computed after the 11 polymorphic nuclear loci. SD: standard deviation.

\begin{tabular}{|lccc|}
\hline Species & $\boldsymbol{P A}$ & $\boldsymbol{I} \pm \mathbf{S D}$ & $\boldsymbol{H}_{\boldsymbol{o}} \pm \mathbf{S D}$ \\
\hline C. chrysocephala & 5 & $1.45 \pm 0.13$ & $0.55 \pm 0.05$ \\
C. emigrantis & 5 & $1.30 \pm 0.23$ & $0.48 \pm 0.30$ \\
C. heldreichii & 1 & $0.80 \pm 0.19$ & $0.30 \pm 0.09$ \\
C. litochorea & 10 & $1.45 \pm 0.23$ & $0.45 \pm 0.09$ \\
C. messenicolasiana & 6 & $1.01 \pm 0.23$ & $0.47 \pm 0.10$ \\
C. princeps & 7 & $1.08 \pm 0.20$ & $0.44 \pm 0.08$ \\
\hline
\end{tabular}

sections Jacea and Lepteranthus. The source species of the markers used in this transferability assay $(C$. corymbosa, $C$. diffusa and C. stoebe) belong to sect. Centaurea. As expected, cross-amplification performed better for $C$. heldreichii, C. messenicolasiana, $C$. chrysocephala, $C$. princeps and C. litochorea, all of them from sect. Phalolepis (eight out of 16 nuclear loci amplified) than for $C$. emigrantis from sect. Lepteranthus (six out of 16 nuclear loci amplified).

Regarding the usefulness of the markers testing the number of alleles, the percentage of polymorphic loci for each species and all the diversity parameters except the number of exclusive alleles were higher for the nuclear loci. As previously explained, the genetic diversity statistics were computed over six species for the nuclear loci and for five species for the chloroplast loci which could bias slightly downwards the values of these parameters for the latter. Nevertheless, we consider that this possible bias can be negligible for the purposes of the present work. In addition, all the nuclear loci tested were polymorphic while 50\% of the chloroplast markers successfully amplified were monomorphic. Again, this denotes that nuclear markers are more variable than chloroplast markers for all the target species assayed regardless of their phylogenetic distance with respect to the source species and therefore they are more informative and suitable for future works.

As far as genetic diversity is concerned, direct comparison of section Lepteranthus and section Phalolepis through the computed statistics is precluded because the SSR markers amplified are not the same for both sections. Moreover, section Lepteranthus is represented by a single species (C. emigrantis) while section Phalolepis is represented by five species.
Table 7. Number of private alleles $(P A)$, Shannon's Information Index $(I)$ and observed heterozygosity $\left(H_{O}\right)$ for each of the 14 polymorphic loci. - : parameters not computed for chloroplast loci and nuclear loci amplified in one single species; *: vaules computed only for $C$. emigrantis. SD: standard deviation.

\begin{tabular}{|lccc|}
\hline Loci & $\boldsymbol{P A}$ & $\boldsymbol{I} \pm$ SD & $\boldsymbol{H}_{\boldsymbol{O}} \pm$ SD \\
\hline CD37 & 3 & $0.46 \pm 0.17$ & $0.27 \pm 0.11$ \\
21CM36 & - & $1.87 \pm-$ & $0.37 * \pm-$ \\
38CM22 & 3 & $0.64 \pm 0.23$ & $0.20 \pm 0.06$ \\
42CM27 & 4 & $1.42 \pm 0.22$ & $0.46 \pm 0.10$ \\
CM17 & - & $1.61 \pm-$ & $0.70^{*} \pm-$ \\
12B1 & 1 & $1.48 \pm 0.11$ & $0.56 \pm 0.11$ \\
13B7 & - & $0.93 \pm-$ & $0.80^{*} \pm-$ \\
13D10 & 4 & $1.08 \pm 0.23$ & $0.44 \pm 0.05$ \\
17E3 & 3 & $1.37 \pm 0.20$ & $0.54 \pm 0.08$ \\
21D9 & 7 & $1.38 \pm 0.40$ & $0.46 \pm 0.14$ \\
28A7 & 4 & $1.43 \pm 0.16$ & $0.60 \pm 0.09$ \\
ccmp3 & 1 & $0.41 \pm 0.13$ & - \\
ccmp4 & 2 & $0.09 \pm 0.06$ & - \\
ccmp5 & 0 & $0.60 \pm 0.11$ & - \\
\hline
\end{tabular}

\section{CONCLUDING REMARKS}

According to our results, the success of the crossamplification is influenced by the evolutionary distance between target and source species. Taken together, the fourteen SSR loci containing more than two alleles will provide an initial backbone for comparative genetic analyses within the genus Centaurea and therefore are selected for further works. This achievement eliminates the need to look for new loci, saving time and money. It is worthwhile highlighting that the nuclear markers provide more information than the chloroplast markers. The results reported here support previous works stating the usefulness of across-taxa amplification of microsatellite markers and should encourage other researchers to follow this approach.

Since the species included in the present work are narrow endemics and/or threatened plants, the study of its genetic diversity is an essential step to design correct strategies for its conservation management. The genetic variability information reported here is merely preliminary and a more accurate work including around 20 or 30 individuals per population is required in order to get robust conclusions regarding the genetic diversity of the species assayed. 


\section{ACKNOWLEDGEMENTS}

Financial support from the Spanish MICINN (Project CGL2007-60781 and CGL2010/18631) and the Generalitat de Catalunya (Ajuts a Grups de Recerca Consolidats 2009/ $\mathrm{SGR} / 00439-G R E B$ ) is gratefully acknowledged. Special thanks to R. Smissen and one anonymous reviewer for many valuable suggestions that greatly improved the manuscript.

\section{REFERENCES}

Anagnostopoulos, A. \& Constantinidis, Th. 1995. Centaurea chrysocephala Phitos \& Georg. In: Phitos, D., Strid, A., Snogerup, S. \& Greuter, W. (Eds.), The red data book of rare and threatened plants of Greece. World Wide Fund for Nature, Athens: 146-147.

Arnelas Seco, I. \& Devesa, J. A. 2010. Contribución al conocimiento cariológico del género Centaurea L. (Asteraceae) en la Península Ibérica. Grupo Jacea-Lepteranthus. Lagascalia 30: 407-445.

Aymerich, P. \& Sáez, L. 2010. Centaurea emigrantis Bubani. In : Sáez, L. Aymerich, P. \& Blanché, C. (Eds.), Llibre vermell de les plantes endèmiques $i$ amenaçades de Catalunya. Argania Editio, Barcelona: 100-101.

Barbará, H., Palma-Silva, C., Paggi, G. M., Bered, F., Fay, M. F. \& Lexer, C. 2007. Cross-species transfer of nuclear microsatellite markers: potential and limitations. Molec. Ecol. 16: 3759-3767.

Chung, S.-M. \& Staub, J. E. 2003. The development and evaluation of consensus chloroplast primer pairs that possess highly variable sequence regions in a diverse array of plant taxa. Theor. Appl. Genet. 107: 757-767.

Constantinidis, Th. 2009. Centaurea litochorea T. Georgiadis \& Phitos. In: Phitos, D., Constantinidis, Th. \& Kamari, G. (Eds.), The red data book of rare and threatened plants of Greece 1. Hellenic Botanical Society, Patras: 227-229 [in Greek].

Cullings, K. W. 1992. Design and testing of a plant-specific PCR primer for ecological and evolutionary studies. Molec. Ecol. 1: 233-240.

Dostál, J. 1976. Centaurea L. In: Tutin, T. G., Heywood, V. H., Burges, N. A., Moore, D. M., Valentine, D. H., Walters, S. M. \& Webb, D. A. (Eds.), Flora Europaea 4. Cambridge University Press, Cambridge: 254-301.

Doyle, J. J. \& Doyle, J. L. 1987. A rapid DNA isolation procedure for small quantities of fresh leaf tissue. Phytochem. Bull. Bot. Soc. Amer. 19: 11-15.

Ebert, D. \& Peakall, R. 2009. Chloroplast simple sequence repeats (cpSSRs): technical resources and recommendations for expanding cpSSR discovery and applications to a wide array of plant species. Molec. Ecol. Resources 9: 673-690.

Eujayl, I., Sledge, M. K., Wang, L., May, G. D., Chekhovskiy, K., Zwonitzer, J. C. \& Mian, M. A. R. 2004. Medicago truncatula EST-SSRs reveal cross-species genetic markers for Medicago spp. Theor. Appl. Genet. 108: 414-422.

Fréville, H., Imbert, E., Justy, F., Vitalis, R. \& Olivieri, I. 2000. Isolation and characterization of microsatellites in the endemic species Centaurea corymbosa Pourret (Asteraceae) and other related species. Molec. Ecol. 9: 1671-1672.

Garcia-Jacas, N., Uysal, T., Romashchenko, K., Suárez-San- tiago, V. N., Ertuğrul, K. \& Susanna, A. 2006. Centaurea revisited: a molecular survey of the Jacea group. Ann. Bot. (Oxford) 98: 741-753.

Georgiadis, Th. \& Dimitrellos, G. 2009. Centaurea princeps Boiss. \& Heldr. In: Phitos, D., Constantinidis, Th. \& Kamari, G. (Eds.), The red data book of rare and threatened plants of Greece 1. Hellenic Botanical Society, Patras: 241-243 [in Greek].

Georgiadis, Th., Dimitrellos, G. \& Routsi, E. 1996. Centaurea messenicolasiana (Asteraceae), a new species of $C$. sect. Phalolepis (Cass.) DC. from Greece. Willdenowia 25: 561-569.

Georgiadis, Th., Krigas, N. \& Constantinidis, Th. 2009. Centaurea messenicolasiana T. Georgiadis, G. Dimitrellos \& Routsi. In: Phitos, D., Constantinidis, Th. \& Kamari, G. (Eds.), The red data book of rare and threatened plants of Greece 1. Hellenic Botanical Society, Patras: 230-231 [in Greek].

Guo, W., Wang, W., Zhou, B. \& Zhang, T. 2006. Cross-species transferability of $G$. arboreum-derived EST-SSRs in the diploid species of Gossypium. Theor. Appl. Genet. 112: 1573-1581.

Hancock, J. M. 1999. Microsatellites and other simple sequences: genomic context and mutational mechanisms. In: Goldstein, D. B. \& Schlötterer, C. (Eds.), Microsatellites. Evolution and applications. Oxford University Press, New York: 1-9.

Heesacker, A., Kishore, V. K., Gao, W. et al. 2008. SSRs and INDELs mined from the sunflower EST database: abundance, polymorphisms, and cross-taxa utility. Theor. Appl. Genet. 117: 1021-1029.

Kantety, R. V., Rotal, M. L., Matthews, D. E. \& Sorrells, M. E. 2002. Data mining for simple sequence repeats in expressed sequence tags from barley, maize, rice, sorghum and wheat. Pl. Molec. Biol. 48: 501-510.

López-Vinyallonga, S., Arakaki, M., Garcia-Jacas, N., Susanna, A., Gitzendanner, M. A., Soltis, D. E. \& Soltis, P. S. 2010. Isolation and characterization of novel microsatellite markers for Arctium minus L (Compositae). Am. J. Bot. Notes and Protoc. Pl. Sci. 97: e4-e6.

Marrs, R. A., Hufbauer, R. A., Bogdanowicz, S. J. \& Sforza, R. 2006. Nine polymorphic microsatellite markers in Centaurea stoebe L. (subspecies C. s. stoebe and C. s. micranthos (S. G. Gmelin ex Gugler) Hayek) and C. diffusa Lam. (Asteraceae). Molec. Ecol. Notes 6: 837-840.

Pashley, C. H., Ellis, J. R., McCauley, D. E. \& Burke, J. M. 2006. EST databases as a source for molecular markers: lessons from Helianthus. J. Heredity 97: 381-388.

Peakall, R., Gilmore, S., Keys, W., Morgante, M. \& Rafalski, A. 1998. Cross-species amplification of soybean (Glycine max) simple sequence repeats (SSRs) within the genus and other legume genera: implications for the transferability of SSRs in plants. Molec. Biol. Evol. 15: 1275-1287.

Peakall, R. \& Smouse, P. E. 2006. GENALEX 6: genetic analysis in Excel. Population genetic software for teaching and research. Molec. Ecol. Notes 6: 288-295.

Phitos, D. \& Damboldt, J. 1971. Beitrage zur Flora Ionica. III. Cytotaxonomische Bemerkungen zu einigen greichschen Compositen. Ann. Naturhist. Mus. Wien 75: 157-162.

Phitos, D., Kamari, G. \& Constantinidis, Th. 2009. Centaurea heldreichii Halácsy. In: Phitos, D., Constantinidis, Th. \& 
Kamari, G. (Eds.), The red data book of rare and threatened plants of Greece 1. Hellenic Botanical Society, Patras: 220-221 [in Greek].

Primmer, C. R., Møller, A. P. \& Ellegren, H. 1996. A widerange survey of cross-species microsatellite amplification in birds. Molec. Ecol. 5: 365-378.

Routsi, E. \& Georgiadis, Th. 1988. IOPB chromosome number reports XCIX. Taxon 37(2): 396-399.

Saha, M. C., Mian, M. A., Eujayl, I., Zwonitzer, J. C., Wang, L. \& May, G. D. 2004. Tall fescue EST-SSR markers with transferability across several grass species. Theor. Appl. Genet. 109: 783-791.

Strid, A. \& Franzen, R. 1981. IOPB chromosome number reports LXXIII. Taxon 30: 829-842.
Suárez-Santiago, V. N., Salinas, M. J., Garcia-Jacas, N., Soltis, P. S., Soltis, D. E. \& Blanca, G. 2007. Evolution by reticulation of the Acrolophus subgroup (Centaurea L., Compositae) in the occidental Mediterranean: origin and diversification of the section Willkommia Blanca. Molec. Phylogen. Evol. 43: 156-172.

Tel-Zur, N., Abbo, S., Myslabodski, D. \& Mizrahi, Y. 1999. Modified CTAB procedure for DNA isolation from epiphytic cacti of the genera Hylocereus and Selenicereus (Cactaceae). Pl. Molec. Biol. Reporter 17: 249-254.

Weising, K. \& Gardner, R. C. 1999. A set of conserved PCR primers for the analysis of simple sequence repeat polymorphisms in chloroplast genomes of dicotyledonous angiosperms. Genome 42: 9-19. 